\title{
Atas do espírito: a Organização Mundial da Saúde e suas formas de instituir a espiritualidade
}

Minutes of spirit: World Health Organization and its ways to institute spirituality

\section{Rodrigo Toniol}

\section{(2) OpenEdition}

\section{Journals}

Edição electrónica

URL: https://journals.openedition.org/aa/2330

DOI: 10.4000/aa.2330

ISSN: 2357-738X

\section{Editora}

Programa de Pós-Graduação em Antropologia Social (UnB)

\section{Edição impressa}

Data de publição: 1 dezembro 2017

Paginação: 267-299

ISSN: 0102-4302

\section{Refêrencia eletrónica}

Rodrigo Toniol, «Atas do espírito: a Organização Mundial da Saúde e suas formas de instituir a espiritualidade», Anuário Antropológico [Online], v.42 n.2 | 2017, posto online no dia 12 junho 2018, consultado o 18 maio 2021. URL: http://journals.openedition.org/aa/2330 ; DOI: https://doi.org/ 10.4000/aa. 2330

\section{(c) $(1)(9)$}

Anuário Antropológico is licensed under a Creative Commons Atribuição-Uso Não-Comercial-Proibição de realização de Obras Derivadas 4.0 International. 


\title{
Atas do espírito: a Organização Mundial da Saúde e suas formas de instituir a espiritualidade ${ }^{1}$
}

\author{
Rodrigo Toniol
}

Unicamp

Em maio de 1984, acadêmicos, técnicos e políticos se reuniram na sede da Organização Mundial da Saúde (OMS), em Genebra, Suíça, por ocasião da 37a assembleia geral da instituição. Entre tantas outras resoluçóes aprovadas naquela ocasiáo, com as quais eu tomava contato a partir da consulta direta aos arquivos da agência, uma em particular reteve minha atenção. Tratava-se da decisão WHA37.13, cujo conteúdo pode ser sintetizado nos seguintes termos:

tendo considerado o relatório da direção geral [da OMS] sobre a dimensão espiritual para o "Programa saúde para todos no ano 2000" e também acompanhando as indicaçōes do Comitê executivo sobre a resolução EB73. R3, a assembleia: [...] Reconhece que a dimensão espiritual tem um papel importante na motivação das pessoas em todos os aspectos de sua vida. Afirma que essa dimensão não somente estimula atitudes saudáveis, mas também deve ser considerada como um fator que define o que seja saúde. Convida todos seus Estados-membros a incluírem essa dimensão em suas políticas nacionais de saúde, definindo-a conforme os padrōes culturais e sociais locais (grifos originais). ${ }^{2}$

Minha surpresa diante da contundência daquela resolução que inscrevia a "dimensão espiritual" como um fator intrínseco à saúde humana só não foi maior que as descobertas acerca da amplitude histórica da presença e, portanto, dos debates sobre essa categoria naquela instituição. Espiritualidade, como descobriria nos meses seguintes de pesquisa na biblioteca e nos arquivos da OMS, é uma noção presente nos documentos oficiais da Organização desde 1948, ano em que foi fundada.

Neste texto me ocuparei da análise das formas de presença da categoria espiritualidade no âmbito da OMS. Para tanto, recorro a atas, memorandos, transcriçôes de discursos, resoluçóes oficiais e relatórios que me permitem explicitar como a ideia de espiritualidade foi acionada ao longo do tempo na instituição e, principalmente, como ela foi articulada com outras noçóes, como as de cultura, religiáo, direitos e bem-estar. Assim, embora por vezes adote uma orientaçáo cronológica para analisar de que modo o termo se estabeleceu nos debates da Organização, não pretendo descrever as modalidades de relação entre espiritualidade e saúde em uma linha histórica contínua e progressiva. Como 
demonstrarei, as formas de instituir essa categoria variam ao longo do tempo sem que isso signifique, no entanto, que diferentes formulaçóes não possam coexistir. Noutras palavras, mesmo em um intervalo de tempo determinado, distintas versóes da espiritualidade podem ser observadas nos documentos da OMS.

Partirei de um movimento de atenção dupla: por um lado, descrevo e analiso as formas instituídas da espiritualidade na OMS, ancorando minhas reflexôes na versão final dos documentos já promulgados; por outro, me atenho aos processos anteriores às oficializações, privilegiando não as formas acabadas das resoluções, mas os debates que as antecederam e as configuraçóes históricas e políticas que as viabilizaram. ${ }^{3}$

Este texto está dividido em duas partes principais. Na primeira, mais curta, explicito algumas das questôes que envolvem a análise do tema da "espiritualidade" nas ciências sociais da religião e justifico as razóes pelas quais uma investigação como esta pode contribuir para tal debate. $\mathrm{Na}$ segunda, detenho-me nos documentos analisados, apresentando-os a partir de dois eixos de variaçáo: a espiritualidade dos Outros e a espiritualidade de Todos. Explicitarei como esses dois eixos não somente diferem, mas principalmente se articulam. Encerro o texto delineando um conjunto de consequências empíricas associadas à "oficialização da espiritualidade" na OMS, assim como elaborando algumas liçôes teóricometodológicas que podemos derivar das análises apresentadas.

\section{Espiritualidade institucionalizada e política da espiritualidade}

Noutros textos (Toniol, 2015a, 2015b), argumentei que a relação entre espiritualidade e saúde tem se consolidado como um tópico cada vez mais frequente e, em alguma medida, legítimo no campo das ciências médicas. Aqui não poderei recuperar cada argumento apresentado, tampouco poderei contemplar as dimensóes controversas desse processo. Sendo assim, limito-me a sublinhar que o reconhecimento da espiritualidade como uma dimensão relativa à saúde é um fenômeno que pode ser observado nas diferentes instâncias do trinômio médico - ensino, pesquisa e clínica - e que tal abrangência também tem despertado a atenção de outros pesquisadores. ${ }^{4}$

Ao mesmo tempo, por mais que os objetivos deste artigo náo estejam diretamente dirigidos a nenhum aspecto imediato da atuação médica, mas sim às formas de produçáo do par espiritualidade/saúde no contexto de uma agência global de gestão da saúde, reconheço que há vínculos e ressonâncias significativas entre as ações da OMS e a dimensão da prática médica. Afinal, como Nitsan Chorev (2012) demonstrou em The World Health Organization between North and South, a produção discursiva sobre saúde e doença realizada no âmbito da OMS 
não é inócua, adquirindo frequentemente concretude local. Para reconhecer tal influência, afirma Chorev, basta observar o papel determinante da agência na definição de políticas nacionais de saúde, na estandardização de procedimentos médicos, ou ainda na formulação de agendas de pesquisa. Essas consideraçóes ajudam a dimensionar como as afirmações da OMS sobre espiritualidade e saúde também podem ter efeitos que ultrapassam o campo da política internacional e afetam, de forma mais direta, o cotidiano de hospitais e ambulatórios.

Tão relevantes quanto a amplitude empírica do fenômeno observado são as consequências teórico-metodológicas que dele podemos desdobrar. Isso porque, como venho argumentando (Toniol, 2016), o caso da legitimação da espiritualidade como uma dimensão da saúde oferece um oportuno contraponto ao modo como os cientistas sociais da religião usualmente empregaram essa categoria e descreveram os fenômenos a ela associados. Entre tantos outros exemplos possíveis, a definição de espiritualidade sugerida por Paul Heelas et al. sintetiza aspectos estruturantes do entendimento do termo para sociólogos e antropólogos dedicados ao assunto: "espiritualidade é uma forma subjetiva de existência do sagrado, que enfatiza fontes internas de significado e de autoridade, assim como o cultivo ou sacralização da vida subjetiva" (2005:6). Definição semelhante a essa foi proposta por Renée de la Torre, que emprega o termo para "aludir a práticas menos dogmáticas, distanciadas das normas e cânones das religióes, [...] [caracterizando-se por serem] individuais, subjetivas, intuitivas e emocionais" (2016:10). Trata-se, prossegue a autora valendo-se do diálogo com Charles Taylor (2007) e Maria Julia Carozzi (1999), de um termo que descreve a "autonomizaçáo do sujeito na busca por uma relação pessoal com o sagrado e com o transcendente, adensada pelo rechaço ao controle institucional e ao autoritarismo das instituiçóes religiosas" (2016:10). Em qualquer dessas duas versóes, a espiritualidade indica uma modalidade de relação com o sagrado estabelecida a partir de contornos desinstitucionalizados e subjetivos.

É certo que essa chave analítica tem sido sido fundamental para o avanço na compreensão de fenômenos como a Nova Era e também do universo dos sujeitos autodeclarados sem religiáo. No entanto, igualmente pertinente é reconhecer que o caráter apriorístico dessas definiçóes de espiritualidade inibiu a atenção dos pesquisadores para outros modos de existência e de usos dessa categoria. Entre esses outros modos de existência da categoria, destaco justamente seu emprego como um dispositivo potente, acionado no âmbito de instituiçóes seculares, que a inscreve em políticas públicas, relatórios de governo, debates jurídicos, textos médicos e, como demonstrarei neste artigo, em resoluçóes, programas oficiais e instruçóes dirigidas à saúde promulgadas pelas OMS. 
A análise a seguir está amparada por um princípio metodológico mais geral que parte do reconhecimento de que espiritualidade é um conceito historicamente situado, marcado pelas configuraçóes de poder características da modernidade ocidental..$^{5}$ A semelhança entre essa afirmação e o que diz Talal Asad (1993:29) sobre a categoria religiáo não é despropositada. Talvez a ordem desse paralelo fique mais clara na paráfrase de outra sentença de Asad (2001:220): definir "espiritualidade" é antes de tudo um ato. Isso significa que a espiritualidade, enquanto categoria, é constantemente definida dentro de contextos sociais e históricos, e que as pessoas possuem razóes específicas para instituí-la de um modo ou de outro. Esse é o ponto de partida que permite o desenvolvimento de análises menos interessadas em definir ou em assumir definiçóes apriorísticas de espiritualidade e mais preocupadas em acompanhar como essa categoria é produzida, sendo mobilizada e mobilizando, em cada uma de suas "versóes", diferentes atores e instituiçóes. É nesse sentido que o caráter vago e plural de espiritualidade, frequentemente tratado como um elemento complicador nas análises de cientistas sociais da religiáo, é convertido no próprio objeto de interesse deste texto. Afinal, o que a multiplicidade de definiçôes do termo sugere é que, primeiro, apesar da variação de sentidos, a recorrência com que ele é acionado não deixa dúvidas: seu emprego não é aleatório. E que, segundo, mais interessante do que definir espiritualidade é "observar como o termo é usado e como as suas diferenciaçóes de outras categorias tornam algumas práticas e engajamentos mais ou menos possíveis" (Bender, 2010:5). Trata-se, portanto, de uma categoria que se estabelece a partir de um equilíbrio precário, entre a pulverização do que pode significar, a insistência de sua relevância e os esforços, por parte de diferentes atores, em defini-la.

Este texto é uma tentativa de avançar no entendimento dos enunciados da OMS sobre a categoria espiritualidade. Ao mesmo tempo, reflete o esforço analítico de dar visibilidade ao termo na sua condição de dispositivo político de gestão de populaçóes - e, portanto, não como um descritor de uma modalidade individual de experiência do sagrado. Refiro-me à gestão de populaçóes porque, afinal, o que está sempre em jogo nessas resoluções da OMS é estabelecer normatizações sobre os vínculos entre espiritualidade e saúde e, simultaneamente, instituir princípios para que seus Estados-membros possam transformá-las em práticas.

Ao deter-me em um contexto no qual a categoria espiritualidade é estabelecida institucionalmente, insisto e estabeleço um contraste latente (nem por isso discordante) com análises dedicadas à espiritualidade em sua versão subjetiva, desinstitucionalizada e oficiosa, tal como aquela implicada na definição de Heelas et al. (2005). O que chamo de espiritualidade institucionalizada remete aos usos 
oficiais, burocráticos ou propriamente institucionais dessa categoria. O contraste é latente porque as formas institucionais de estabelecimento da espiritualidade, mesmo quando o termo é forjado como uma variável de políticas de populaçóes, náo necessariamente desfazem o vínculo entre a categoria e a experiência individual e subjetiva. Trata-se, contudo, de um tipo de formulação que reconhece o caráter possivelmente individual da espiritualidade, transformando-o em uma questáo que transcende as individualidades.

É preciso sublinhar que a noção de espiritualidade institucionalizada é próxima da que o antropólogo Peter van der Veer denominou de política da espiritualidade. Em seu livro Modern spirit of Asia (2013), Veer também estava interessado em apontar para o caráter normativo que o termo pode assumir. Em seu caso, no entanto, a atenção estava dirigida ao emprego da categoria em expedientes de exercício do poder colonial na Índia e na China. Ainda assim, apesar das evidentes diferenças entre os materiais empíricos analisados, tanto nas pesquisas de Peter van der Veer quanto na investigaçáo que originou este texto, declarar o interesse pelas formas institucionais de produção da espiritualidade significa colocar no centro das reflexóes os efeitos, as configuraçôes históricas e os interesses implicados em cada ato de definição dessa categoria. Diante dos documentos da OMS, portanto, o que interessa não é perguntar "afinal, o que é espiritualidade?", mas sim "quais são os atores envolvidos, os termos mobilizados e os efeitos implicados cada vez que essa categoria é instituída?”

Ao dizer, portanto, que as reflexóes que seguem estáo às voltas com certa política da espiritualidade, aponto para os processos que normatizam a categoria espiritualidade e, ao mesmo tempo, transformam-na em uma dimensão normatizadora de políticas de saúde. Nesse sentido, o uso que faço da noção de política aproxima-se da literatura condensada em trabalhos como o de Cris Shore e de Susan Wright (2003) sobre a antropologia da política, mas talvez esteja ainda mais dirigido ao que Michael Herzfeld (2008) denominou de "poética do Estado".

Em seu livro Intimidade cultural, Herzfeld (2008) opera substancialmente dois conceitos: o de poética (social) e o de intimidade cultural. Como bem sintetizou Marcio Goldman (1998), a "intimidade cultural" seria constituída por valores que os indivíduos e grupos consideram como "seus" e que eles devem, ao mesmo tempo, seguir e apresentar aos demais. Representam-se os valores no sentido teatral do termo, mas isso só adquire sentido no quadro das interaçóes concretas, que, simultaneamente, produzem os contextos em que se processam (Goldman, 1998:150). É nessa apresentação criativa do eu individual que se situa a "poética do social”. Ocorre, e é isso o que me interessa no texto de Herzfeld, que o Estado e, eu acrescentaria, as agências de governança, como a OMS, também têm sua poética. 
E parte essencial dessa poética consiste justamente no "esforço para apagar todos os rastros de sua própria criatividade, ao mesmo tempo em que busca impedir a de todos os demais". Afinal, como afirma Herzfeld (2008:40), "o Estado-nação está comprometido ideologicamente com a sua perpetuação ontológica para toda a eternidade. Embora possa tentar adotar a mudança tecnológica ou até social, ele perpetua a ilusão semiótica da fixidez cultural". E é por isso, continua o autor noutro trecho, "que as ideologias oficiais costumam recusar a instabilidade semântica: reconhecendo que a instabilidade levaria ao apercebimento de que os próprios sentidos oficiais são instáveis" (Herzfeld, 2008:41).

As consequências dessa perspectiva para estabelecer a contribuição da antropologia para os estudos do Estado e de outros organismos de gestão são definitivas. A partir dela, o trabalho antropológico passa a ser o de reinserir "a consciência do fundamento social, cultural e político mesmo do poder mais formal e do conhecimento mais abstrato" (Herzfeld, 2008:46). O antropólogo que encarar esse Estado-naçáo em seus planos de existência mais concretos - aqueles das experiências vividas pelos indivíduos e grupos que nele habitam - perceberá imediatamente, sugere Herzfeld, que o que se denomina com esse nome (Estado) consiste, na verdade, em um conjunto aberto de agentes e operaçóes, possuindo como denominador comum o fato de estarem voltados para uma "despoetização" da vida social, ou seja, para a essencialização, naturalização e literalização de experiências sociais sempre múltiplas e polifônicas. ${ }^{6}$

Ao situar seu interesse na dimensão mais concreta desse conjunto aberto de agentes e operaçóes, Herzfeld reconhece, na reflexão sobre o cotidiano e sobre a produção de documentos por burocratas e agentes estatais, uma via privilegiada de acesso ao problema da poética do Estado. Afinal, esses sujeitos têm à disposição uma variedade excepcionalmente rica dos próprios dispositivos de apresentação do Estado, uma vez que são autores de leis, burocracias, políticas públicas etc., que emergem (quase) sem deixar rastros e terminam servindo para reificar essa aparente imutabilidade estatal (Herzfeld, 2008:54).

A perspectiva de Herzfeld oferece um enquadramento analítico oportuno para situar o movimento que faço neste artigo de analisar os debates e os documentos que retratam decisóes do trabalho burocrático da OMS. Sem perder de vista a poética do Estado, afinal, também estou interessado na apresentação formal da espiritualidade por parte da OMS, aposto aqui na análise de documentos que me aproximam dessa espécie de ato de despoetização, que sinteticamente é uma tentativa de escapar da imagem poderosa de que as decisóes tomadas no âmbito de uma agência como essa estão orientadas pela pura racionalidade técnica. 


\section{Documentos instituídos, documentos instituintes}

O material empírico que fundamenta este texto é sumariamente documental. Tive acesso a ele explorando variaçooes da palavra "espiritualidade" — "espírito", "espiritual" etc. - nas bases de dados dos arquivos físicos e digitais disponíveis em acervos da OMS e da Organização das Naçôes Unidas (ONU).7 O resultado inicial foi a seleção e análise de um conjunto de 1.497 documentos, datados entre 1948 e 2017, distribuídos entre memorandos, atas, relatórios, resoluções, livros comemorativos etc. Diante desse volume de informaçôes, não faltam possibilidades classificatórias. Seria possível, por exemplo, produzir uma classificação baseada nos materiais que instituem "espiritualidade" como a) uma dimensão da saúde mental; b) um fator protetivo de saúde; e c) um vetor indicativo de qualidade de vida. $\mathrm{Ou}$, ainda, classificá-los a partir da diferenciação entre as proposições que avançaram nas instâncias deliberativas da OMS e aquelas que fracassaram. Embora factíveis e relevantes, essas formas de organização tornam-se limitadas quando lhes impomos uma linha temporal mais ampliada. Isso porque algumas dessas formas de instituir espiritualidade refletem tendências de períodos específicos do debate sobre o tema, inviabilizando, assim, a observação de transformaçóes mais gerais e temporalmente distribuídas.

Foi considerando aspectos como esse que optei por privilegiar dois eixos narrativos e de organização desses documentos. Trata-se de eixos que me permitem tanto contemplar as variaçóes da espiritualidade na OMS ao longo de uma série histórica ampliada como também sublinhar algumas características dessas formulaçôes, que são contínuas. Assim, primeiro descreverei as condiçóes da formulação e os documentos que instituem o que chamei de espiritualidade dos Outros. E, na sequência, deter-me-ei na espiritualidade de Todos. Como ficará explícito a seguir, tão importante quanto identificar diferenças entre essas formas de instituir espiritualidade é reconhecer que há uma dinâmica de conexão entre elas, evidenciando-se como a elaboração de uma foi imprescindível para o estabelecimento de outra.

\section{Espiritualidade dos Outros}

A OMS foi criada em 1948 como uma agência da ONU, investida da autoridade e da responsabilidade de coordenar açóes internacionais de atenção à saúde. Tal como outras instituiçốes criadas em meados do século XX, logo após a experiência de duas grandes guerras, a OMS foi estabelecida com o desígnio de "instituir normas e padrôes de atendimento, articular políticas de gestão da saúde, prover suporte técnico e monitorar as açôes locais de seus Estados-membros". Seu principal objetivo, descrito em sua constituição inaugural, é tão vago quanto 
ambicioso: "a conquista do mais alto nível de saúde possível para todos os povos". ' Diante dele, a funçấo da OMS estaria concentrada em dois movimentos fundamentais: de um lado, garantir universalidade do acesso a serviços de saúde de qualidade para as populaçóes menos favorecidas; de outro, criar mecanismos de controle e ação sobre epidemias globais que, por suas características, ultrapassam limites fronteiriços e, portanto, cujo combate depende de açóes internacionais coordenadas.

Embora os objetivos e a agenda atual da OMS permaneçam em consonância com aqueles estabelecidos quando da sua fundação, os meios empregados para atingi-los, assim como o tipo de ação internacional realizada pela agência, transformaram-se radicalmente durante a década de 1960. Nesse período, os processos de independência de antigas colônias, seguidos do reconhecimento dessas novas nações pelas instituições de governança global, alteraram as dinâmicas de negociação, os debates e as deliberações em todo o sistema das Nações Unidas.

No início dos anos de 1970 as condiçóes político-econômicas globais que informaram as políticas da Organização Mundial de Saúde durante suas primeiras décadas de existência já estavam radicalmente transformadas. Os novos Estados independentes, com o fim do período colonial, uniram-se ao bloco dos entáo chamados países de terceiro mundo, e juntos eles passaram a constituir o grupo majoritário no sistema das Naçóes Unidas e em suas agências especializadas [como a OMS]. Isso transformou a dinâmica das forças políticas internacionais. A emergência de uma agenda de cooperação entre países latino-americanos, asiáticos e africanos também resultou na unificação de críticas sobre os países desenvolvidos que, segundo esse bloco emergente, atuavam para comprometer a efetivaçáo de todo o potencial econômico de suas regiōes. Em 1974, tais acusaçóes foram formalizadas na Assembleia Geral das Naçōes Unidas, que terminou conclamando a emergência de uma Nova Ordem Econômica Internacional (NOEI). A NOEI estava baseada em um conjunto de princípios fundamentais que incluíam equidade, justiça e soberania econômica dos países (Chorev, 2012:42).

Essa nova configuração política e econômica também afetou as ações da OMS. As antigas colônias, a partir de então países independentes, passaram a demandar mais autonomia na gestão de suas políticas de saúde e também a adaptação dos programas da agência global às singularidades locais. Situar essa conjuntura é fundamental para compreendermos as razóes e justificativas que viabilizaram a consolidação de uma das formulaçóes mais recorrentes da espiritualidade nos documentos da OMS: aquela que a institui, associando-a à cultura e à medicina tradicional. Para dar conta desse processo, no entanto, é 
necessário recuperar as açôes de outra agência que atuava globalmente na gestão da saúde - uma agência não de base secular, como a da ONU, mas sim religiosa.

Três anos após o fim da Segunda Guerra Mundial, a reboque da criação de uma série de instituiçóes globais que tinham como objetivo fortalecer e ampliar a visibilidade política de iniciativas até então não articuladas, foi criado o Conselho Mundial de Igrejas (CMI). Desde sua fundação, o CMI foi estruturado a partir de frentes de trabalho orientadas por objetivos próprios e com autonomia de agendas, mas convergentes com os princípios mais gerais da organização, tais como o ecumenismo e a promoção e participação em projetos de desenvolvimento regional. Entre essas frentes de trabalho está a chamada Comissão de Médicos Cristãos (CMC), criada em 1968, estabelecida em Genebra e especialmente voltada para a gestão de uma rede de hospitais e ambulatórios construídos com o apoio do CMI. Essa comissáo também foi criada com a incumbência de assumir a coordenação das açôes de saúde que o Conselho realizava nos países em que suas missóes médicas atuavam, principalmente na África, Ásia e América Latina.

A antropóloga Pamela Klassen, em sua pesquisa sobre liberalismo e medicina entre grupos protestantes no século XX, identificou a fundação da Comissão de Médicos Cristãos, na década de 1960, e os trabalhos por ela desenvolvidos como um ponto de ruptura em relação às missões médicas evangélicas anteriores. Até aquele momento, afirma Klassen, a atuação dos médicos-missionários estava baseada em um modelo centralizador, que privilegiava a construção de grandes hospitais nos centros urbanos, apoiados pelos governos coloniais daqueles territórios - modelo semelhante àquele também adotado pela OMS. A mudança política da condição colonial, no entanto, tornou esse modelo insustentável e, aliado a isso, as mudanças no próprio trabalho de missão do CMI, cada vez mais aderente ao discurso do diálogo inter-religioso, configuraram um quadro que impeliu as novas "missóes médicas" noutra direção. A CMC estabeleceu, formalmente, uma agenda baseada numa perspectiva pós-colonial, orientada por um ideal holístico e concebida para aproximar agentes de saúdes da realidade dos enfermos (Klassen, 2011). Essas são as palavras-chave do modelo denominado pela $\mathrm{CMC}$ como "atenção primária à saúde" - termo que posteriormente adquiriria amplas repercussóes em políticas de saúde, em grande medida pelos desdobramentos do contexto que descreverei a seguir. Entre outros aspectos significativos do deslocamento promovido pela CMC, que particularmente interessa aos propósitos desse texto, está o status atribuído aos "curandeiros tradicionais". Anteriormente desprezados por médicos missionários, no novo modelo, esses agentes foram integrados à estrutura de saúde e, principalmente, capacitados para atuar em uma rede de cuidado mais capilarizada no interior dos países. 
É nesse ponto que a estratégia de atuação adotada pela CMC para responder à nova situação política dos países coloniais encontra ressonâncias com o próprio perfil de ação missionária orientado pelo CMI. Como também observou Klassen (2011), os profissionais que atuavam na CMC forjaram o modelo de atenção primária à saúde a partir de uma linguagem e de formas que já vinham progressivamente sendo adotadas em missôes médico-religiosas. Acompanhando a retórica do amor ecumênico e da universalidade humana, o protestantismo liberal passou da ênfase na assistência médica evangelizadora para aproximaçóes que enfatizavam o trabalho colaborativo com a comunidade local, a valorização de suas formas de conhecimento e a conceitualização da noção de "saúde" como um princípio "holístico".

A importância desse último aspecto não deve ser subestimada. Christoph Benn e Erlinda Senturias, médicos que atuaram naquele período na Comissão, por exemplo, reconhecem que a abertura para as técnicas tradicionais de cura foi possível somente na medida em que os "missionários adotaram um modelo de atenção que já não privilegiava a caridade ou que tivesse qualquer ideal proselitista, mas que, pelo contrário, apostava nos benefícios do cuidado holístico" com o qual os curadores locais também poderiam contribuir (2001:12). Esses novos aliados, os curadores locais, afirmam Benn e Senturias (2001), tornaram-se peças-chaves, já que apenas eles poderiam realizar práticas de cuidado culturalmente compatíveis com a noção de corpo e, principalmente, de espírito de seu grupo.

$\mathrm{O}$ modelo de trabalho adotado pela CMC estabeleceu uma associação entre práticas de medicina tradicional e, em seus próprios termos, atenção à dimensão espiritual. Dois aspectos precisam ser retidos neste ponto. Primeiro, por conta da transformação no modo de ação missionária, conforme as orientações do CMI, o contato com populaçóes "nativas" estava orientado por ideais ecumênicos e, portanto, não concorrenciais, já que não tinha como objetivo primeiro a conversão. Isso permitiu que a CMC reconhecesse a legitimidade das "práticas de atenção e de cuidado com o espírito" realizadas pelas populaçóes por ela atendidas. A segunda dimensão a ser sublinhada nesse contexto é que essas formas de cuidado com o espírito foram descritas, pelo CMC, como práticas de saúde. Esse processo não é trivial, já que se refere à transformação de sujeitos que, pouco tempo antes, eram considerados pela mesma instituição como "sacerdotes de religióes pagãs" em "agentes legítimos de cura". 10

Aqui, no entanto, não são as ações da $\mathrm{CMC}$ o que interessa propriamente, mas sim reconhecer como essas açóes impactaram o posicionamento da OMS sobre o tema da espiritualidade. De antemão, sublinho que o modelo instituído pela CMC, que articula medicina tradicional e cuidado com o que passaria a ser 
denominado de "espiritualidade", foi precursor de um processo que também seria empregado na OMS, inaugurando uma série de formulaçóes que associa a ideia de espiritualidade com práticas de saúde não ocidentais. É, ao fim e ao cabo, a espiritualidade dos Outros que passa a ganhar forma.

Em novembro de 1970, a CMC publicou o primeiro volume de um periódico criado com o objetivo de divulgar crônicas e relatos dos trabalhos que estavam sendo realizados pelos médicos cristãos. Significativamente intitulada Contact, a publicação, que descrevia projetos e ações da CMC, chamou a atenção de delegados e funcionários da OMS que enfrentavam problemas semelhantes àqueles ali apresentados. Essa é a justificativa explicitada pelo diretor geral da OMS, Tom Lambo, ao enviar uma correspondência a James McGilvray, então diretor da CMC, em novembro de 1973, propondo "uma reunião entre os diretores da Comissão de Médicos Cristãos e um grupo de delegados da Organização, com o objetivo de explorar possibilidades efetivas de trabalho conjunto" (Klassen, 2011:54).

Conforme os registros, o encontro ocorreu apenas em março de 1974 e contou com a presença de 10 delegados seniores da OMS, além de membros da CMC. Entre os delegados da OMS estava Kenneth Newell, cujo pai havia trabalhado no CMI entre o fim da década de 1940 e o início de 1950. Segundo relatos, a reuniáo teve como principal resultado a criação de um pequeno grupo de trabalho, coordenado por Newell e por um diretor da CMC, incumbido de preparar um relatório que indicasse a viabilidade de parcerias de longo prazo entre as duas agências e também apresentar propostas mais imediatas, a ser levadas à assembleia geral da OMS daquele mesmo ano (Litsios, 2004).

Apenas três meses depois da reunião e da criação do grupo de trabalho, em julho de 1974, durante a 27a Assembleia Mundial de Saúde, a OMS aprovou uma resolução que recomendava "assistir os governos de seus Estados membros na condução de suas políticas de saúde em direção aos seus próprios objetivos, tendo como prioridade o rápido e efetivo desenvolvimento de seus sistemas de saúde". ${ }^{11}$ Como sugere Socrates Litsios (2004), delegado da OMS à época, esse texto iniciou a abertura da instituição ao modelo de atenção primária à saúde, o que era explicitamente um resultado da parceria com a CMC. Ainda mais explícita quanto a adesão da OMS aos projetos originários das novas missóes médicoreligiosas foi a criaçáo, naquela mesma Assembleia, do Programa de Atenção à Saúde Primária, cuja coordenação foi atribuída a Newell, também coordenador do comitê de parceria entre OMS e a CMC.

Em 1978, esse programa organizou, em Alma-Ata, então território da União Soviética, a Conferência Internacional sobre Cuidados Primários de Saúde, 
evento que se tornou uma referência constante nas políticas de saúde elaboradas posteriormente. Entre outros marcos, foi nesse evento que a noção de "medicina tradicional" foi propriamente estabelecida e instituída na OMS. Em texto oficial, o termo é definido como "a soma total de conhecimentos, habilidades e práticas baseadas em teorias, crenças e experiências nativas de diferentes culturas, explicáveis ou não, usadas na manutenção da saúde, bem como na prevenção, nos diagnósticos e no tratamento de adoecimento físicos e mentais". ${ }^{12} \mathrm{Ou}$ ainda, em um documento mais recente:

ao longo da história, os asiáticos, africanos, árabes, as populaçóes nativas americanas, da Oceania, centro-americanas, sul-americanas, e de outras culturas, têm desenvolvido uma grande variedade de sistemas tradicionais nativos. [...] A medicina tradicional pode se codificar, regular, ser ensinada e praticada aberta e sistematicamente, além de se beneficiar de milhares de anos de experiência. ${ }^{13}$

Fica explícito, na definição estabelecida pela OMS, que as experiências e práticas da categoria "medicina tradicional" têm como características: a presunçáo de vínculo com sistemas culturais, a origem não ocidental e a distância da linguagem biomédica. Fundada na cultura, situada historicamente num passado distante e geograficamente afastada do Ocidente, a legitimação da medicina tradicional acompanha, em termos muito semelhantes, a legitimaçáo que os médicos-missionários também já haviam estabelecido em seus projetos.

Esse fato interessa a este texto porque foi a partir da legitimação da medicina tradicional que "espiritualidade" passou ser uma categoria mais frequente nos documentos da OMS. Isso porque, no entendimento da Organização, por mais variadas que sejam, as medicinas tradicionais operam a partir de técnicas que incluem "tratamento espiritual" e dirigem-se a populaçóes que concebem a saúde como uma totalidade que integra "corpo, mente e espírito". ${ }^{14}$ Em síntese, medicina tradicional é a medicina dos Outros, que, por suas condiçóes culturais específicas, conceberiam a dimensão espiritual como uma face incontornável de seu processo de cura. Nessa formulação, tamanho é o vínculo pressuposto entre o mundo não ocidental com a dimensão espiritual que, para a OMS, disso o Ocidente inclusive poderia receber uma lição:

medicina tradicional não deve ser desenvolvida para o seu próprio bem, mas sim porque todas as forças devem ser mobilizadas para que alcancemos saúde para todos nos anos 2000. Isso [medicina tradicional] pode também nos enriquecer, expandir nossos conhecimentos médicos e científicos, e ainda ampliar a riqueza espiritual da humanidade..$^{15}$ 
A cadeia de conexôes apresentada até aqui é extensa: em 1968, a CMC é fundada e restabelece o modelo de atuação dos projetos de saúde do CMI; esses projetos, que fundam a noção de atenção primária à saúde, baseiam-se na valorização dos conhecimentos tradicionais e na ideia de que a saúde dessas populações demanda atenção holística; nesse contexto, a CMC institui a passagem que transforma os antigos "sacerdotes de práticas nativas" em "agentes de saúde", com os quais passa a buscar estabelecer relaçóes; em 1974, a OMS oficializa uma parceria institucional com a Comissão e incorpora o modelo de atenção primária à saúde; quatro anos depois, a medicina tradicional é oficializada na OMS e, assim, introduz um novo enquadramento possível para a presença da ideia de espiritualidade nos documentos da Organização: uma fórmula que culturaliza a categoria e a atrela às necessidade de atenção à saúde dos povos não ocidentais.

É nesse contexto que podemos situar um número significativo de documentos da OMS que vinculam a ideia de espiritualidade ao processo de legitimaçáo das chamadas medicinas tradicionais. Nesse modelo, insisto, a espiritualidade reconhecida pela OMS é aquela que se corresponde com formas de tratamento e cura muito particulares, características de apenas uma parcela do globo: os Outros do Ocidente moderno (e biomédico).

Estabelecida inicialmente na década de 1970, a associação entre formas culturais específicas de compreensão do processo de saúde-doença, as práticas de medicina tradicional e a noçáo de espiritualidade continuaram sendo descritas nos documentos da OMS. Por exemplo, um documento de 2006 do Comitê Regional das Américas para Saúde afirma:

populações indígenas têm uma visão holística do mundo. A abordagem holística pressupóe que o todo é maior do que a soma das partes. Ao incorporar paradigmas nativos passa-se a se conceber saúde por suas relaçóes dinâmicas e pelo equilíbrio que pressupóe entre as dimensôes inseparáveis do indivíduo (físico, mental, emocional e espiritual). ${ }^{16}$

Até aqui argumentei e demonstrei como a noção de espiritualidade na OMS foi instituída como parte da legitimação de medicinas tradicionais. Essa formulação condiciona sua legitimidade, como fator de saúde, a grupos culturalmente específicos. No entanto, se, por um lado, nos documentos da OMS dirigidos aos contextos da África e América as práticas de medicina tradicional são usualmente descritas de forma genérica, enfatizando-se a necessidade de atenção diferencial às populaçôes nativas dessas regiōes, por outro lado, as resoluçóes endereçadas ao Oriente, majoritariamente, não descrevem as características culturais dos grupos, mas sim a qualidade terapêutica de suas práticas. Trata-se 
de uma inversão fundamental, que dá centralidade às características das práticas e não às necessidades dos grupos que as praticam. Fundamental, repito, porque essa inversão desassocia a noção de espiritualidade das necessidades de grupos específicos e a vincula, alternativamente, às práticas desses grupos. Assim, abre-se a possibilidade de formular a espiritualidade em termos de prática e não de cultura. Isso indica uma mudança do enquadramento da noção de espiritualidade, que, portanto, deixa de estar constrita ao campo das medicinas dos Outros e passa a ganhar espaço nas políticas e recomendaçôes globais, culturalmente indistintas.

O caso da yoga é emblemático da indicaçáo dessa passagem dos documentos que inscrevem a espiritualidade como uma dimensão da outridade e aqueles que a situam como um princípio de saúde pertinente para a saúde de todos. A justaposição de dois documentos da OMS é ilustrativa. No primeiro, intitulado Medicina tradicional na Ásia, publicado em 2002, a yoga é descrita como uma “jornada espiritual [...], uma prática de desenvolvimento para a evolução espiritual, mas que pode ser facilmente empregada para o alívio de doenças". ${ }^{17}$ Já no segundo documento, voltado para o tema do bem-estar mental, a prática continua sendo descrita em termos de sua potência para o incremento da dimensão espiritual, mas esse benefício não é territorializado no âmbito das medicinas tradicionais, e sim no campo da ciência, a partir do qual a prática se desculturaliza e torna-se recomendável como técnica de prevenção, cuidado e bem-estar.

Atualmente, há evidências "cientificamente validadas" em vários níveis, desde estudos de caso até ensaios randomizados duplo-cegos controlados por placebo, que atestam a eficácia de algumas técnicas psicoespirituais. O maior conjunto de evidências tem sido sobre a meditação e a Yoga. Vários desses estudos sugerem que a Yoga é benéfica para o controle de fatores de risco de doenças coronárias, como também é eficaz contra hipertensão, obesidade, dislipidemia, estresse mental e diabetes mellitus. De acordo com estudos científicos, a yoga pode atrasar a progressão da doença cardiovascular aterosclerótica ou mesmo fazê-la regredir. Yoga náo tem efeitos colaterais e tem baixo custo. Portanto, recomenda-se difundi-la [entre os países membros da OMS] como uma técnica saudável e holística de promoção do bem-estar físico e mental e eficaz para a prevenção de doenças cardíacas e outras doenças relacionadas ao estilo de vida. ${ }^{18}$

É nesses termos que, nos documentos da OMS, o caráter antes restrito de necessidade de atenção à dimensão espiritual adquire contornos prescritivos e, assim, torna-se uma recomendação generalizante. Essas observações são fundamentais porque elas nos dão pistas sobre uma questão pouco enfrentada nas pesquisas sobre espiritualidade e saúde no âmbito da medicina oficial, qual seja: por que algumas práticas terapêuticas são associadas aos cuidados com o 
espírito e outras não? Ou, de modo mais preciso, sendo ambas reconhecidas como medicina tradicional, porque a Yoga popularizou-se como uma prática possível e viável em instituiçôes médicas e, por exemplo, a fitoterapia dos curandeiros de Gana permaneceu restrita ao interior daquele país?

Certamente há muitas mediaçóes implicadas na produção dessa diferença de popularidade e legitimidade de práticas orientais (yoga, medicina tradicional chinesa, tai chi chuan, acupuntura, etc) e medicinas tradicionais de outros territórios. Entre essas mediaçóes, as mais evidentes talvez sejam a do empenho de pesquisas científicas, no Ocidente, dirigidas às práticas orientais, e também o próprio fascínio e construção da imaginação que vincula o oriente à espiritualidade - ambos tópicos tratarei noutros capítulos. Ainda assim, a partir da análise dos documentos da OMS também podemos observar a consolidação dessa retórica naquela agência. Em síntese, práticas como a Yoga foram inscritas de outra maneira na chave da medicina tradicional da OMS por meio de dois recursos principais: 1) porque sempre foi descrita como uma prática terapêutica e não como um fenômeno cultural de um grupo específico, sendo, portanto, descrita como uma prática e náo como uma manifestação da alteridade; 2) porque a partir do processo anterior essa prática foi rapidamente desterritorializada e tornada um recurso médico, uma técnica que, nos termos da OMS e repetindo a citaçáo anterior, "é saudável e holística [ uma forma de] promoção do bem-estar físico e mental, eficaz para prevenção de doenças cardíacas e outras doenças relacionadas ao estilo de vida".

A seguir investirei nessa outra forma discursiva de presença da noção de espiritualidade na OMS, demonstrando como ela se prolifera em discursos sobre práticas terapêuticas, mas também se compatibiliza com outras noçóes como a de direto à saúde e de bem estar.

\section{Espiritualidade de Todos}

Considerando o conjunto de documentos da OMS que podem ser agrupados porque oficializam a espiritualidade numa chave generalizante - isto é, não particular, como nos casos que descrevi da espiritualidade dos Outros —, destaco três formas recorrentes, sobre as quais me detenho a seguir.

\section{Espiritualidade e práticas terapêuticas}

Nos anos seguintes ao evento de 1978 da OMS, quando a medicina tradicional foi reconhecida, outro conjunto de práticas terapêuticas igualmente de base náo biomédica foi oficializado pela Organização: as chamadas medicinas alternativas e complementares (MAC). ${ }^{19}$ Em comum a ambos os conjuntos está a projetada 
afinidade com a dimensão espiritual; e, em contraste, o fato de que as MACs, desde sua criação, não são descritas em função das populaçóes que as praticam, mas sim de suas qualidades terapêuticas.

A MAC é uma categoria afim à Medicina Tradicional (MT). Ao menos nos documentos oficiais da OMS, esses termos são assim constituídos, sendo apresentados, inclusive, pela sigla MT/MAC. No entanto, eles têm trajetórias distintas na instituição, a exemplo de sua pressuposta localização: enquanto a MT corresponde a práticas do Sul global, MACs são práticas características do Norte, como fica explícito no relatório da OMS sobre a presença dessas práticas no mundo: "o uso de medicina tradicional segue sendo muito extenso em países em desenvolvimento - Índia (70\%), Ruanda (70\%) e Etiópia (90\%). E em países desenvolvidos - como Estados Unidos, Austrália, Canadá e Reino Unido -, o uso de medicina alternativa e complementar tem aumentado muito rapidamente". ${ }^{20}$

Há uma diferença evidente nas formas de vínculo territorial de cada um desses conjuntos de práticas. Enquanto o território e a cultura são condicionantes da MT — isto é, na concepção da OMS, cada população mantém sua própria prática de MT, que por sua vez perde sentido fora desse contexto —, as práticas de MAC operam fora de qualquer condicionamento territorial ou cultural. Nem por isso o endereçamento das MACs aos países do Ocidente moderno é menos significativo. Isso porque, ao fazê-lo, a OMS inicia um processo de legitimação de práticas não biomédicas, alegadamente forjadas numa perspectiva holística $\mathrm{e}$ atentas à dimensão espiritual, em um contexto onde anteriormente não havia espaço para considerações sobre a pertinência da atenção à espiritualidade.

Operando novamente como um princípio-chave, o holismo é um termo síntese da própria definição de MAC, bem como indicador da amplitude do tipo de atenção que tais práticas buscam prover. Entre os documentos oficiais que sintetizam essa característica das MACs estão os textos das Políticas de Práticas Integrativas e Complementares (PICs), que, no Brasil, oficializaram a oferta de terapias como a homeopatia, a fitoterapia, a acupuntura e o reiki no Sistema Único de Saúde. Em um desses documentos oficiais, por exemplo, esse conjunto de terapêuticas é descrito como "práticas para a promoção, proteção e recuperação da saúde, que pressupóe o usuário/paciente na sua integralidade física, mental, emocional, social, ambiental e espiritual". ${ }^{21}$

A conexão entre espiritualidade e MAC é estabelecida pela OMS por uma espécie de duplo princípio. Primeiro, essas práticas são definidas e justificadas em razão do entendimento de que a natureza da pessoa é uma totalidade que abrange corpo, mente e espírito - em contraste com o caso da MT, aqui o cuidado holístico não é baseado no sistema cultural de um grupo, mas justificado 
em termos da própria natureza humana. Segundo, como já afirmei, a atenção à dimensão espiritual é descrita como uma qualidade terapêutica da qual algumas práticas estão imbuídas. Insisto nesses dois princípios porque eles são chave no processo histórico de ampliação da pertinência do par espiritualidade/saúde, antes restrito aos Outros do Ocidente e, em seguida, "autonomizado da cultura" e reconhecido como necessário para saúde de Todos.

Acompanhando os documentos da OMS, especialmente aqueles publicados após os anos 2000, é possível observar como a progressiva legitimação da atenção à espiritualidade também tem impactado os protocolos alinhados com a própria biomedicina. Por exemplo, em um dos principais documentos da OMS sobre tratamento de pessoas com câncer constam afirmaçóes como "[...] pacientes [com câncer] devem ser questionados sobre os aspectos espirituais de sua vida e isso deve ser considerado na condução de seu tratamento"; 22 ou, ainda, "[em casos de pacientes com câncer,] a avaliação clínica é essencial e não deve ter como base apenas aspectos físicos, mas também sociais, psicológicos e espirituais". ${ }^{23}$

Diante disso, insisto na não aleatoriedade do emprego dessa categoria, argumentando que, longe de ser contingencial, esse processo de legitimação e oficialização da qualidade clínica da espiritualidade está relacionado com uma longa trajetória de debate e disputa sobre a pertinência do termo na OMS. Para compreender e situar essas disputas e formas ainda mais ampliadas do uso da categoria, no entanto, é necessário extrapolar os casos em que espiritualidade é descrita a partir de sua dimensão terapêutica.

\section{Direito à espiritualidade}

A primeira menção ao termo "espiritualidade" nos documentos oficiais da OMS ocorreu ainda em 1948, apenas seis meses após a criação da instituição. Naquele momento, o tópico não fora abordado por uma demanda dos delegados da agência, mas teve que ser deliberado por conta da solicitação, encaminhada pela Organização das Nações Unidas (ONU), do posicionamento da OMS sobre a nova versão da Declaração dos Direitos das Crianças, documento que originalmente havia sido proclamado em 1924, ainda sob os auspícios da Liga das Naçôes. Quase um quarto de século depois, a ONU se encarregou de preparar uma atualização do texto da Declaração. Apesar da relevância política do primeiro acordo internacional que reconheceu a existência de direitos específicos para as crianças, o texto da década de 1920 era sucinto. Estruturava-se a partir do seguinte preâmbulo e continuava com a descrição de cinco compromissos: "por meio desse acordo, homens e mulheres de todas as naçóes reconhecem que a humanidade tem o compromisso de oferecer o melhor às crianças, além e sobre qualquer consideraçáo 
de raça, nacionalidade ou credo". ${ }^{24} \mathrm{Na}$ sequência, o primeiro compromisso do texto afirmava: "as crianças devem ter assegurados todos os requisitos para seu normal desenvolvimento, tanto material quanto espiritual". 25

A defesa do direito ao desenvolvimento espiritual descrito naquela declaração prenuncia uma forma de inscrição do termo que também ganharia espaço nos documentos da OMS, quando a espiritualidade seria descrita como uma dimensão dos direitos das pessoas. Naquele momento, contudo, esse foi justamente um dos poucos pontos em que os delegados da OMS sugeriram modificaçôes. No entendimento deliberado na OMS, o trecho do preâmbulo da Declaraçáo de 1924 deveria suprimir a ênfase na garantia ao "desenvolvimento material e espiritual" das crianças, para estabelecer que "as crianças devem ter assegurados todos os requisitos para seu normal desenvolvimento físico, mental e social, por meio da provisão de cuidados e adequadas condiçóes de moradia, nutrição e educação [...]". ${ }^{26}$

A proposição estava em franco diálogo com as dimensóes que a OMS havia descrito, no texto de fundação da própria organização, como definidoras da saúde humana. A sugestão encaminhada era parte de uma estratégia institucional para amplificar as repercussóes dos princípios orientadores daquela agência. A proposta, no entanto, não foi acatada pela $\mathrm{ONU}$ e, quanto a menção à espiritualidade, a Declaraçáo dos Direitos das Crianças promulgada em 1948 manteve o formato original. Aliás, onze anos depois, em 1959, a ONU promulgou uma nova versão do documento, dessa vez retirando a referência aos "aspectos materiais", incorporando algumas sugestóes encaminhadas pela OMS, mas mantendo a centralidade da categoria espiritualidade. Em 1989, a Declaraçáo foi novamente atualizada e, nessa versão, a brevidade das anteriores deu lugar a um texto extenso, com 54 artigos e outros tantos incisos. Nela, o emprego do termo "espiritualidade" não apenas foi mantido, tal como no original de 1924, como se tornou ainda mais recorrente, constando em cinco novos trechos do texto.

Apesar de a posição dos delegados da OMS em 1948 ter sido pela supressão do termo "espiritualidade", nos anos seguintes, acompanhando o que também fica explícito ao seguirmos a trajetória de atualizaçôes da Declaração dos Direitos das Crianças, a espiritualidade não apenas se tornou uma categoria constante, como também seu uso passou a ser crescente nos textos da própria OMS.

Em 1984, na resolução já citada anteriormente, uma das reuniôes da assembleia mundial de saúde recomendou que a "espiritualidade" fosse incorporada como uma das dimensôes da saúde humana, sugerindo, assim, a definição: "saúde é um estado dinâmico de completo bem-estar físico, mental, espiritual e social, e não meramente a ausência de doença ou enfermidade". A proposta teve consequências 
extensas, tendo se tornado chave para que a espiritualidade, uma vez considerada uma dimensão da saúde humana, fosse instituída como um direito noutros documentos da OMS e também em políticas nacionais de saúde. Para compreendêla, no entanto, é preciso retroceder alguns anos.

A intensidade das mençôes ao termo "espiritualidade" nos documentos analisados deu um salto a partir do final da década de 1970. Entre 1978 e 1982, ampliaram-se as ocasiôes em que delegados e diretores da OMS mencionaram a pertinência e a necessidade de atençáo à espiritualidade. Naquele período, ao fazê-lo, usualmente chamavam a atenção para a ausência do debate. Em 1978, por exemplo, o delegado da Líbia avaliou uma resolução da Organização sobre saúde de adolescentes, ponderando que "o relatório não fez referência aos valores espirituais e ao seu impacto no desenvolvimento [...] e na manutenção de hábitos saudáveis" ${ }^{27} \mathrm{Na}$ mesma ocasião, o delegado da Índia foi ainda mais explícito e prenunciou o que de fato ocorreria alguns anos depois: "[...] a dimensão espiritual deve ser adicionada aos já contemplados aspectos físicos, mentais e sociais da saúde". ${ }^{28}$ Posição semelhante foi assinalada no ano seguinte pelo delegado das Ilhas Fiji: "é lamentável que a ênfase no aspecto espiritual não seja articulada com o desenvolvimento e equilíbrio das faculdades físicas e mentais. [...] [A] OMS deveria estudar o impacto da dimensão espiritual na saúde". ${ }^{29}$

Em 1983, durante a 36a Assembleia Geral da OMS, o debate sobre espiritualidade adquiriu outros contornos, deixando de estar disperso em mençóes que assinalam sua ausência na Organização para se tornar pauta oficial na agenda do principal encontro da instituição. Acompanhando retrospectivamente a transcrição das reunióes e dos debates das atividades realizadas naquele período, é possível identificar um posicionamento particular como desencadeador dos eventos que se sucederam. Trata-se de uma manifestação do delegado da Suazilândia, o médico Samuel Hynt, que conclamou:

o programa [Saúde para Todos no Ano 2000] pode ter todos os ingredientes para ser bom e bem-sucedido, mas falta a ele contemplar a dimensão espiritual. Posso ser acusado de introduzir algum conceito religioso na OMS, mas gostaria de ver a saúde definida em nossa Constituição desta forma: "a saúde é um estado de completo bem-estar físico, mental e espiritual". Antes que os especialistas legais me desestimulem, vejo que o caminho para alcançar isso é fazer com que o Diretor-Geral acolha uma emenda sobre o tema, que deve ser proposta por nós pelo menos seis meses antes da Assembleia Geral de Saúde. Aqueles que desejam se juntar a mim na proposição deste conceito, me avisem. Se fizermos isso agora, teremos 12 meses para fazer o lobby, os arranjos e preparar o debate sobre o tema antes da 38a Assembleia Mundial da Saúde em 1984. ${ }^{30}$ 
A proposta manifesta por Hynt não era elementar: alterar o conceito-chave da Constituição da OMS, reinstituindo, assim, a própria definição de saúde e, por conseguinte, inscrevendo a "dimensão espiritual" como parte da responsabilidade dos Estados-naçáo no cuidado com a saúde de suas populaçôes. Se o que descrevi na seção anterior aponta para a autonomização cultural da noçáo de espiritualidade, cada vez mais aproximada das práticas terapêuticas, a proposta de Hynt era ainda mais ampla, concebendo a espiritualidade como uma necessidade universal da saúde humana.

Essa proposição, que uma década antes seria improvável de ocorrer e mais ainda de repercutir, tinha naquele momento um terreno fértil para ser continuada. Primeiro porque as resoluçôes sobre MT e, na sequência, MAC rotinizaram a aproximação entre cuidado holístico, atenção primária e atenção à dimensão espiritual da saúde. Sobre esse ponto, também é preciso sublinhar que, embora não fosse discursivamente hegemônica, a noção de MT implicava diretamente um número significativo de países, já que abrangia a maior parte dos territórios da África, Ásia e América Latina. E isso se relaciona com a segunda razão da força que a convocação de Hynt teve naquele momento: com as mudanças políticas ocorridas durante a década de 1960, o modo de votaçáo dos projetos na OMS foi equalizado na proporção de um voto por país, o que significava que a soma dos votos dos países com MT, hipoteticamente mais dispostos a esse diálogo, era maior do que o bloco formado por Europa Ocidental e Estados Unidos. Igualmente relevante é o fato de que Hynt, embora representasse um pequeno país africano, independente há menos de uma década naquele momento, estava articulado e tinha o apoio da CMC, que continuava ativa em suas parcerias com a OMS.

Hynt foi um médico missionário escocês que viveu na Suzilândia desde seus seis meses de vida, quando seus pais, também médicos, transferiram-se para a região com o propósito de expandir as missões médicas da Igreja do Nazareno, fundada no Reino Unido por seu avô, também médico, George Sharpe. Os pais de Hynt foram bem-sucedidos em seu propósito: fundaram a igreja no país e criaram um hospital missionário, uma rede de ensino e, pelo menos, uma universidade. Hynt assumiu a diretoria do hospital (Raleigh Fitkin Memorial Hospital) em meados do século XX, quando o modelo de ação proposto pelo CMC já estava em vigor. Ao longo de sua vida, além de delegado do país na OMS, Hynt foi ministro da saúde e médico da família real da Suazilândia. Agia, assim, naquela Assembleia em 1983, como mais um ator e articulador em um espaço fronteiriço, que implicava a OMS, médicos missionários e Estados nacionais emergentes do Sul global. ${ }^{31}$ 
Dez dias depois da convocação feita por Hynt, uma proposta de resolução relativa à dimensão espiritual da saúde foi incluída na agenda de debates da Assembleia. Embora extenso, reproduzo a seguir o texto da proposta e parte dos debates a ela relativa, registrados numa sequência de três sessóes plenárias. Vale destacar que, no debate, há uma única manifestação feita por alguém que não era delegado de algum país membro da OMS - justamente a primeira intervenção, proferida por um representante do CMC.

[...] Considerando que a dimensão espiritual está implícita no conceito de saúde; Tendo em mente a política adotada pela Organização de assegurar cuidados de saúde primários para todos os povos do mundo, a fim de atingir o objetivo social da saúde para todos até o ano 2000; Reconhecendo a contribuição que a dimensão espiritual pode oferecer para provisão de melhores cuidados de saúde. [A OMS]:

Afirma a importância da dimensão espiritual nos cuidados com a saúde.

2. Solicita ao Diretor-Geral que tome em consideração a dimensão espiritual na preparação e desenvolvimento de programas de cuidados de saúde primários voltados para a concretização do objetivo de 'saúde para todos até o ano 2000'.

Dr. Ram (Comissão de Médicos Cristãos). Falo aqui graças ao convite do Diretor. Lembro a todos que a CMC, vinculada ao Conselho Mundial de Igrejas, teve uma frutuosa relação consultiva com a OMS na última década. [...] Nos últimos 15 anos, a CMC gerenciou programas médicos de suas igrejas em todo o mundo. Sempre procuramos ir além dos programas de medicina hospitalar, adotando uma abordagem comunitária de cuidados primários em saúde. Com o sucesso desses programas, a OMS considerou que era o momento de implementá-los em larga escala, contando com a parceria e experiência dos médicos-missionários. A CMC apoia plenamente os esforços de vários membros da OMS que advogam pela afirmação da importância da dimensão espiritual na prestação de cuidados de saúde. [...] Desde 1977, a Comissão Médica Cristã participou de 10 encontros regionais [da OMS] realizados em diferentes lugares do mundo. Observamos frequentemente mençôes sobre como todas as dimensôes, inclusive a espiritual, deve ser considerada nos cuidados de saúde [...] Atender as outras necessidades básicas de saúde é importante, mas está claro que o equilíbrio entre esses aspectos e a dimensão espiritual também é um elemento essencial para a conquista do objetivo da saúde para todos até o ano 2000.

Dr. Savel'Ev (URSS). Manifesto-me sobre o projeto de resolução da dimensão espiritual nos programas de cuidados de saúde. Minha delegaçáo tem todo o respeito pelas opinióes religiosas dos delegados. Os aspectos religiosos certamente desempenham um papel importante na organização dos serviços de saúde em alguns países - embora enfatizo que esse não seja universalmente o caso. No 
entanto, um encaminhamento dessa natureza ao Diretor-Geral poderá colocálo em sérios problemas, uma vez que há uma grande diversidade de perspectivas religiosas no mundo e seria extremamente difícil para ele levar todas elas em consideração na preparação do texto dos programas sobre cuidados primários em saúde. Uma solução melhor seria que cada Estado-Membro interessado tomasse medidas próprias sobre isso quando planejarem seus programas nacionais de atenção primária. Caso contrário, eu teria que apresentar inúmeras emendas a essa resolução. Só depois dessas emendas esse projeto de resoluçáo poderia refletir a posição de minha delegação e de vários países de nossa região. ${ }^{32}$

Dr. Al-Saif (Kwait). Os delegados estão tentando implementar uma política na OMS que pretende garantir saúde para todos até o ano 2000. Para isso é preciso levar em conta o papel da dimensão espiritual no trabalho de cuidado da saúde. Estou dizendo que os cuidados de saúde, incluindo a prevenção e o tratamento, devem ter em conta os componentes mentais e espirituais da natureza do homem. Seja qual for o progresso tecnológico feito, náo pode haver um progresso verdadeiro enquanto os corpos dos homens forem tratados sozinhos, sem considerar sua alma. [...]

Dr. Klivarová (Tchecoslováquia). Minha delegação também está em uma posição bastante difícil, porque considera que a resolução não pode ser aceita por todos os Estados membros da Organização, uma vez que se baseia em certas crenças religiosas. Há diferentes crenças religiosas em diferentes países, bem como há países com muitos ateus. $\mathrm{Na}$ Tchecoslováquia, por exemplo, ateus e crentes têm os mesmos direitos. Portanto, minha delegação não pode aprovar o projeto de resolução proposto.

Dr. Hamdan (Kwait). Eu achava que nem era preciso dizer quáo importante é a dimensão espiritual para o bem-estar do homem, especialmente considerando os sentidos de pertencimento a uma comunidade que essa dimensão gera.

Sr. Weitzel (Alemanha Ocidental). Minha delegação está em uma posição embaraçosa porque não sabemos mais o que está sendo discutido. $\mathrm{O}$ texto do projeto de resolução menciona "dimensão espiritual", mas as delegaçôes estão falando de uma "dimensão religiosa". Talvez o que esteja sendo discutido até seja uma "dimensão mental". Por essa razão, apreciaríamos muito qualquer esclarecimento sobre o que está sendo entendido como "dimensão espiritual".

Dr. Houénassou-Houangbé (Togo). Fico um pouco surpreso com toda essa discussão sobre um projeto de resoluçáo que já deveria ter sido votado e aprovado. Como médico e trabalhador de saúde não entendo o porquê da idéia de dimensáo espiritual ofender algumas pessoas ou por qual razão alguns parecem acreditar que isso tem como objetivo criar uma religiáo dos cuidados primários em saúde. Como acabamos de sugerir, a dimensão espiritual pode ser qualquer coisa, desde o ateísmo mais puro até o mais puro fanatismo. 
Diretor-geral. Náo sei bem qual é a melhor maneira de refletir sobre essa questão. Examinei a definição de "espírito" no Oxford English Dictionary e a primeira definição dada foi a "parte inteligente ou imaterial do homem, alma"; sobre "espiritual" define-se: "de espírito, em oposição à matéria". Ao mesmo tempo, também é verdade que há muitas outras definições para esses termos no dicionário, o que também cria uma grande quantidade de pontos de interrogação para qualquer um. [...] Para mim, pessoalmente, estou de acordo que há uma dimensão espiritual no homem, no sentido expresso pelo Oxford Dictionary. Se poderia haver uma dimensão espiritual nos programas de cuidados de saúde, disso não tenho tanta certeza.

Dr. Hamdan (Emirados Árabes Unidos) Alguns anos atrás a medicina popular ou a medicina tradicional eram inaceitáveis nos programas de saúde dessa Organização. Essas práticas foram rejeitadas e consideradas fora das tendências do desenvolvimento dos serviços de saúde no mundo. Atualmente essas práticas são amplamente aceitas e agora começamos a discutir um assunto que pode parecer difícil de encarar, mas é preciso olhar para o futuro. Eu conheço muitos países onde a medicina espiritual desempenha um papel importante na saúde. Por que a OMS deveria se recusar a incluir essa dimensão em sua Estratégia Global? Por que não experimentamos?33

Dr. Al-Saif(Kwait) O que se entende por dimensão espiritual não é religião nem doutrina. Qualquer pessoa que considere que esse projeto de resoluçáo tenha implicaçóes religiosas ou dogmáticas está enganada. Essa dimensão não é nada mais que o lado espiritual do homem, isso não está relacionado com as religiōes ou doutrinas que eles seguem.

Ao fim das discussóes aprovou-se a proposta de resolução por 80 votos a favor, 33 contra e 12 abstençōes. ${ }^{34}$

$\mathrm{Na}$ sequência dessa resolução, ao fim e ao cabo aprovada, outras propostas de natureza semelhante foram apresentadas na OMS. Em comum, todas estabelecem que: 1) a espiritualidade é uma dimensão inequívoca e universal da saúde — em algumas resoluçôes, não é descrita como uma universalidade da saúde, mas sim da pessoa; 2) sendo a espiritualidade uma dimensão da saúde (ou da pessoa), a atenção espiritual é um aspecto fundamental do cuidado. Ambas as formulaçóes reforçam e sedimentam o eixo de enunciação, na OMS, da espiritualidade como uma característica de todos - no final desta seção há um quadro que sintetiza as principais datas e eventos mencionados anteriormente.

O debate em torno dessa formulação também pode ser descrito como uma tensão entre os delegados que, favoráveis à proposta, afirmaram a universalidade da ideia de espiritualidade e aqueles contrários ao encaminhamento, que rejeitavam a resolução argumentando que espiritualidade é um objeto de crença, 
equivalente a religiâo e, portanto, individual. A antropóloga Winnifred Sullivan tratou de questôes que mantêm algum paralelo com a situação aqui descrita. Em seu livro $A$ ministry of presence, a autora trata das transformaçóes recentes do serviço de capelania nos hospitais militares e civis do Estados Unidos. Para Sullivan, a progressiva legitimação do par espiritualidade/saúde foi uma das principais justificativas para que o status dos "capelães" em contextos de saúde fosse alterado de "especialistas limitados a assistência religiosa" para "profissionais treinados para compor equipes de saúde" ou "experts no tratamento da dimensão espiritual da saúde". Esses profissionais, afirma Sullivan, "deixaram de falar em nome de alguma confissão ou identidade religiosa particular e passaram a tratar da espiritualidade como um aspecto natural e universal de todos os seres humanos" (2014:3). Tal como também poderíamos afirmar sobre a OMS, Sullivan conclui, comentando os casos que analisou: "ao menos nos Estados Unidos, embora a lei se apresente como secular, todos os cidadãos são crescentemente entendidos como universal e naturalmente religiosos - necessitando de cuidado espiritual" (2014:160).

Para a autora, esse fato é suficiente para afirmar que a categoria "espiritualidade consiste em um novo modo de estabelecimento da religião ou, no limite, um modo de dissimular a religião em espaços seculares" (2014:200). Nesse ponto, assumo minha divergência com Sullivan. Reconheço que espiritualidade possa ser o novo avatar da religiáo em espaços públicos ou em instituiçóes como a OMS. Isso não significa, no entanto, que essa categoria seja redutível a um "disfarce da religião" ou que ela não possa ser instituída, de fato, noutros termos. Com relação à conclusão de Sullivan, trata-se de uma dupla divergência: empírica, porque a análise dos documentos da OMS explicita o vigor com que essa categoria pode ser articulada com outras noçôes; e também metodológica, já que partir da presunção de que "espiritualidade é religião" invisibiliza outras formas de existência e formulação dessa categoria.

Nas situações apresentadas nesta seção, por exemplo, é inegável que a CMC tenha novamente tido um papel importante para instituir a noção de espiritualidade na OMS. Isso não significa, no entanto, que esse processo possa ser reduzido à atuação dos médicos missionários e tampouco que seus desdobramentos estejam restritos aos interesses desse grupo. É o que fica explícito quando identificamos outra forma de instituir a espiritualidade de Todos, dessa vez, não argumentando que ela é um direito, mas estabelecendo-a como fator relevante para a produção de uma métrica do bem-estar. Valho-me desse último conjunto apresentado também para tecer os comentários conclusivos deste texto. 


\section{Quadro 1}

\section{Quadro sintético de datas relevantes mencionadas}

1948. Criação da Organização Mundial da Saúde (OMS)

1948. Recomendação, pelos delegados da OMS, de retirar a categoria espiritualidade da Declaração dos Direitos das Crianças

1948. Criação do Conselho Mundial de Igrejas (CMI)

1968. Criação da Comissão de Médicos Cristãos (CMC), vinculada ao CMI

1968-1969. Estabelecimento do modelo de atenção primária desenvolvido pela CMC

1970. Publicação da revista Contact para divulgar as experiências da CMC

Março de 1974. Primeira reunião de colaboração entre CMC e OMS e criação de um grupo de trabalho para aproximação das instituições

Julho de 1974. Primeira menção ao termo "saúde primária" na OMS, durante a 27ạ Assembleia Mundial de Saúde. Resultado direto da atuação do grupo de trabalho criado meses antes.

1978. Realização da Conferência Internacional sobre Cuidados Primários de Saúde organizada pela OMS. Aprovação da noção de MT em termos semelhantes aos estabelecidos pela CMC. Com essa noção, a OMS reconhece o que chamei de "espiritualidade dos Outros"

1979. Início da demanda pelo reconhecimento da "espiritualidade de Todos"

1983. Ampliação dos discursos sobre a necessidade do amplo reconhecimento da espiritualidade como fator de saúde na OMS

1984. Aprovação, em assembleia da OMS, da resolução que reconhece a espiritualidade como dimensão da saúde e que recomenda a atenção a ela em políticas nacionais

\section{Comentários finais - a espiritualidade de todos testada}

Iniciei este texto assinalando a necessidade de atenção à espiritualidade institucionalizada, isto é, de atenção às formas de instituir essa categoria como um dispositivo político, com impactos concretos na vida das populaçóes. Argumentei que, para tanto, dois movimentos analíticos eram necessários. Primeiro, recusar definiçóes apriorísticas dessa categoria optando, em contrapartida, por acompanhar as variadas formas como ela é instituída, mobilizando e sendo mobilizada por atores diversos. E, segundo, seguir os processos de institucionalização da espiritualidade reconhecendo que isso também implica entrar em tensão com a perspectiva analítica dominante nas ciências sociais, que emprega essa categoria para tratar de formas individuais, subjetivas e desisntitucionalizadas de relação com o sagrado. Esses 
movimentos, como espero ter explicitado nas páginas anteriores, produzem um enquadramento analítico para o tema da "espiritualidade" que não está ancorado em suas presumidas vinculações com religião, mas, pelo contrário, que aposta nos benefícios de acompanhar as variações nas formas de definir essa categoria. É isso, inclusive, o que me permitiu tratar das aproximaçóes entre religião e espiritualidade na OMS a partir de um quadro mais denso e complexo do que aquele que poderia produzir caso analisasse a segunda em função da primeira. É também nesses termos, reconhecendo a autonomia discursiva que a categoria espiritualidade vem adquirindo no campo da saúde, que se pode identificar como a espiritualidade também tem sido instituída como parte de indicadores de bem estar. Trata-se, em certo sentido, de um novo movimento na direção do que chamei de espiritualidade de todos, dessa vez, tanto se ampliando com relação aos "sujeitos espiritualizados" como também diversificando a fonte de legitimação dessa noção de espiritualidade, que agora inclui, mais intensamente, marcadores científicos.

É possível traçar um paralelo temporal entre a expansão do interesse pela espiritualidade na OMS e o emprego do termo em pesquisas médico-científicas. Embora esses processos estejam marcados por atores distintos e por dinâmicas próprias, também não é forçoso assumir que entre eles opere uma relação de legitimação mútua - algumas vezes explícita, do lado da OMS, por meio de resoluçôes que aprovam o apoio e o financiamento de pesquisas sobre o tema, outras vezes expressa, no campo da ciência, em justificativas de pesquisas clínicas que fazem referência às resoluçóes da OMS sobre o tema. É a partir dos anos de 1990, no entanto, que a imbricação desses dois campos gera um produto concreto, endereçado ao tema da espiritualidade: o instrumento de avaliação de espiritualidade, religiosidade e crenças pessoais para qualidade de vida da OMS. Com a primeira versão publicada em 1998, esse instrumento é resultado da participação direta de pesquisadores de mais de 30 instituiçóes, que contribuíram para elaborá-lo e para validar estatisticamente sua aplicação em diferentes regióes do mundo.

Naquele período, precisamente em 1998, o tema da espiritualidade havia voltado a ser debatido pelo comitê principal da OMS. Em reunião executiva da direção da OMS, a demanda pela inclusão da "dimensão espiritual” na definição de saúde da instituição havia sido aprovada, e os comitês regionais já começavam a repercutir tal decisão amplificando o uso da categoria em suas políticas locais. A repercussão do termo no recém-criado instrumento de avaliação de qualidade de vida não foi diferente. Em sua versão final, legitimada por parâmetros estatísticos e instituída pela OMS como protocolo para que seus Estados membros atingissem os índices desejados de saúde, o instrumento abordava seis domínios, considerados 
fundamentais para o aferimento da qualidade de vida das populações: saúde física, saúde psicológica, nível de independência, relaçôes sociais, ambiente e espiritualidade, religião e crenças pessoais. ${ }^{35}$

Noutro texto, descrevi pormenorizadamente como ao longo das décadas de 1960 e 1970 as noçóes de holismo, bem-estar e qualidade de vida operaram no campo dos saberes psi e fomentaram a realização de pesquisas sobre espiritualidade (Toniol, 2015b). Também indiquei que questionários muito semelhantes aos que seriam posteriormente empregados pela OMS foram os instrumentos de investigação privilegiados dessas pesquisas. Ao contrário daquela análise, na qual estive interessado nas variaçóes desses questionários, detendo-me nas mudanças no entendimento da espiritualidade a partir de transformaçóes metodológicas dessas pesquisas, desta vez o que interessa é o fato, em si, da institucionalização, pela OMS, da espiritualidade como um domínio fundamental da qualidade de vida. Desse fato, retenho dois aspectos que me parecem centrais para a conclusão deste texto.

Primeiro, diferentemente das formulaçóes anteriores, nesse caso, a espiritualidade não é uma manifestação cultural particular, tampouco descreve uma qualidade terapêutica de certas práticas ou consiste em uma das dimensóes do direito à saúde. Quando tornada índice de qualidade de vida, a espiritualidade é convertida em uma constante universal cuja variação pode ser traduzida em um fator empiricamente mensurável. Trata-se de um novo regime possível do eixo espiritualidade de todos. Segundo, ao ser convertida em um domínio de qualidade de vida, agrega-se a essa versão da espiritualidade institucionalizada pela OMS o sinal positivo. Promulgada nesses termos, espiritualidade torna-se não somente uma dimensão que diz respeito a todos, como também um domínio do aperfeiçoamento de si, da promoção de saúde e da melhoria do bem-estar. A espiritualidade é instituída, nesses documentos, em correlação com qualidade de vida, ou seja, "espiritualidade faz bem" - quanto melhor estiver, maior será o indicador de qualidade de vida.

As resoluçôes da OMS sobre qualidade de vida encerram o conjunto mais recente dos documentos dirigidos ao tema da espiritualidade, que é significativo pela abrangência e pela sugestiva positivação, e cujas consequências fora das políticas globais de gestão da saúde ainda são imprecisas. Isso não nos impede, no entanto, de identificar que esse tipo de formulaçáo possa funcionar como uma espécie de senha para que a atenção à espiritualidade seja progressivamente incorporada em protocolos clínicos, como algumas situaçóes já parecem nos sugerir (Toniol, 2015a). Esse apontamento nos leva de volta ao quadro de análise que sustenta e, ao mesmo tempo, justifica este texto. A dificuldade em analisar 
a "espiritualidade" nas ciências sociais não está na falta de definiçôes para o termo, mas decorre das posiçóes que fazem da tarefa de defini-lo um ato anterior à própria análise das formas em que ele já opera, organizando realidades. $\mathrm{O}$ antídoto para esse imbróglio, sugiro, acompanhando Courtney Bender e Omar McRoberts (2012), é voltar-se para essa categoria a partir de sua história (seja como categoria analítica das ciências sociais, seja como fenômeno empírico), para as articulaçóes que ela estabelece (com outras categorias, como religião, cultura e natureza) e também para suas formas institucionalizadas, cada vez mais visíveis em instituiçóes seculares ou religiosas. Enfim, abordagens que façam das variadas formas de existência da espiritualidade seu próprio objeto de atenção, tal como busquei fazer ao longo deste texto.

Recebido em 11/12/2017

Aprovado em 29/01/2018

Rodrigo Toniol é doutor em antropologia e pesquisador da Unicamp. Contato: rodrigo.toniol@gmail.com. 


\section{Notas}

1. Este texto é resultado de um projeto de pesquisa apoiado pela Fapesp. A pesquisa que o fundamenta foi realizada durante o período em que fui pesquisador visitante no Departamento de Filosofia e Estudos de Religiáo da Universidade de Utrecht. Debati versóes preliminares deste artigo com os colegas do projeto "Religious matter in an entangled world", coordenado por Birgit Meyer. Nominalmente, agradeço à Birgit Meyer pelas sugestôes ao artigo, assim como pela acolhedora recepção em Utrecht. Também agradeço a Emerson Giumbelli, Fabiola Rohden, Fernanda Heberle e Lucas Baccetto pela interlocução durante a escrita deste artigo. Por fim, devo mencionar os pareceristas anônimos do Anuário Antropológico pelos comentários precisos.

2. Documento consultado: A37/33, 15 de maio de 1984. Arquivos OMS.

3. Todo material consultado e mencionado neste artigo estava na forma de texto, inclusive os debates, que objetivamente eram transcriçóes.

4. Refiro-me tanto a pesquisadores das ciências sociais, com os quais dialogo ao longo deste texto, como a pesquisadores de outras áreas do conhecimento (para citar apenas alguns: Castellar, Fernandes \& Tosta, 2014; Charlier et al., 2017; Liao, 2017; Reginato, Benedetto \& Gallian, 2016; Saad, de Medeiros \& Mosini, 2017; Senel \& Demir, 2018).

5. Sobre a relação entre espiritualidade e modernidade, ver: Veerz $(2009,2013)$, Bender (2010) e White (2008).

6. Há aqui um encadeamento de ideias semelhantes ao que apresentou Márcio Goldman (1998:151) em uma resenha do livro de Herzfeld.

7. Essas consultas foram realizadas entre março e agosto de 2017. Parte dos documentos foi obtida por meio da pesquisa in loco, na biblioteca da sede da OMS, em Genebra (Suíça), e outra parte foi acessada por meio da coleção especial disponível em arquivos digitais da biblioteca da Universidade de Utrecht. Para o levantamento em ambos os acervos, busquei referências aos termos "espírito", "espiritual" e "espiritualidade". O resultado dessa busca foi de aproximadamente 2.000 documentos, entre os quais descartei aqueles que se repetiam. Como indico a seguir, terminei com um volumoso material de 1.497 arquivos que li integralmente para elaborar esta sistematização.

8. Documento consultado: Constituiçấo da OMS, 1988, p.1. Arquivos OMS.

9. Constituição da OMS, 1988, p.1. Arquivos OMS.

10. Esse é um processo extenso ao qual podem ser associados muitos aspectos, entre eles a própria antropologia (Klassen, 2011) e a paulatina legitimação da noção de holismo no campo da saúde (Toniol, 2014).

11. Documento consultado: SEA/RC27/11, julho de 1974. Arquivos OMS.

12. Documento consultado: Legal status of traditional medicine and complementary/ alternative medicine: a worldwide review. 2001. 
13. Documento consultado: Estrategia de la OMS sobre medicina tradicional 20022005. 2002.

14. Documento consultado: Legal status of traditional medicine and complementary/ alternative medicine: a worldwide review. 2001.

15. Documento consultado: EB/63, janeiro de 1979. Arquivos OMS.

16. Documento consultado: CD47/13, 2006. Arquivos OMS.

17. Documento consultado: Traditional Medicine in Asia. 2002. p. 94, p. 100. Arquivos OMS.

18. Documento consultado: Regional Workshop on Promotion of Mental WellBeing, 2009. p. 13. Arquivos OMS.

19. Não é possível apresentar uma lista fechada das práticas implicadas nessa categoria. Limito-me a mencionar homeopatia, reiki, floral, cromoterapia e fitoterapia.

20. Documento consultado: Estrategia de la OMS sobre medicina tradicional 20022005. 2002.

21. Documento consultado: Rio Grande do Sul. Secretaria Estadual da Saúde. Resolução no 695/13 - CIB/RS. Porto Alegre, 2013.

22. Documento consultado: Manual on the prevention and control of common cancers, 1998. Arquivos OMS.

23. Manual on the prevention and control of common cancers, 1998. Arquivos OMS.

24. Documento consultado: EB/2, 1948. Arquivos OMS.

25. EB/2, 1948. Arquivos OMS.

26. EB/2, 1948. Arquivos OMS.

27. Documento consultado: EB/61, 1978. Arquivos OMS.

28. EB/61, 1978. Arquivos OMS.

29. Documento consultado: WHA32/ A32/B/SR/15, 1970. Arquivos OMS.

30. Documento consultado: WHA/36 - A36/VR/5, 4 de maio de 1978. Arquivos OMS.

31. Sites consultados: https://goo.gl/JVH4iQ e https://goo.gl/wLCEvz (acesso em: 7/12/2017). Os países que assinaram o encaminhamento do pedido inicial de votaçáo foram: Arábia Saudita, Bahrein, Botswana, Chile, Egito, Iêmen, Quênia, Kuwait, Malawi, Mauritânia, Marrocos, Oman, Qatar, Síria, Somália, Suazilândia, Sudão, Tunísia, Emirados Árabes, Venezuela e Zâmbia.

32. Documento consultado até este trecho: A36/A/SR/14, 13 de maio de 1983. Arquivos OMS.

33. Documento consultado até este trecho: A36/A/SR/15, 14 de maio de 1983. Arquivos OMS

34. WHA36/1983/REC/2, 16 de maio de 1983. Arquivos OMS.

35. Documento consultado: WHO/HIS/HSI Rev.2012.03, 1998. Arquivos OMS. 


\section{Referências}

ASAD, Talal. 1993. Genealogies of religion: discipline and reasons of power in Christianity and Islam. Baltimore: The Johns Hopkins University Press.

2001. "Reading a modern classic: W. C. Smith's The Meaning and End of Religion”. History of Religions, 40(3):205-222.

BENN, Christoph \& SENTURIAS, Erlinda. 2001. "Health, healing and wholeness in the ecumenical discussion". International Review of Mission, 90(356-357):7-25.

BENDER, Courtney. 2010. The new metaphysicals: spirituality and the American religious imagination. Chicago and London: University of Chicago Press.

BENDER, Courtney \& MCROBERTS, Omar. 2012. Mapping a field: why and how to study spirituality. New York: Social Science Research Council, Working Group on Spirituality, Political Engagement, and Public Life.

CASTELlAR, Juarez I., FERNANDES, César A. \& TOSTA, C. Eduardo. 2014. "Beneficial effects of pranic meditation on the mental health and quality of life of breast cancer survivors". Integrative Cancer Therapies, 13(4):341-350.

CHARLIER, Philippe et al. 2017. "A new definition of health? An open letter of autochthonous peoples and medical anthropologists to the WHO". European Journal Of Internal Medicine, 37:33-37.

CAROZZI, Maria Julia. 1999. A nova era no Mercosul. Petrópolis: Vozes.

CHOREV, Nitsan. 2012. The World Health Organization between North and South. New York: Cornell University Press.

DE LA TORRE CASTELLANOS, Renée. 2016. "Presentación: la espiritualización de la religiosidad contemporánea”. Ciencias Sociales y Religión, 18(24):10-17.

GOLDMAN, Marcio. 1998. Cultural intimacy: social poetics in the nation-state. Mana, 4(2):150-153.

HEELAS, Paul et al. 2005. The spiritual revolution: why religion is giving way to spirituality. London Blackwell.

HERZFELD, Michael. 2008. Intimidade cultural: poética social no Estado-Nação. Lisboa: Ediçóes 70.

KLASSEN, Pamela E. 2011. Spirits of Protestantism: medicine, healing, and liberal Christianity. Oakland: University of California Press.

LIAO, Lester. 2017. "Spiritual care in medicine". Jama, 318(24):2495-2496. 
LITSIOS, Socrates. 2004. "The Christian Medical Commission and the development of the World Health Organization's Primary Health Care Approach”. American Journal of Public Health, 94(11):1884-1893.

REGINATO, Valdir; BENEDETTO, Maria Auxiliadora C. D. \& GALLIAN, Dante M. C. 2016. "Espiritualidade e saúde: uma experiência na graduação em medicina e enfermagem”. Trabalho, Educação e Saúde, 14(1):237-255.

SAAD, Marcelo; DE MEDEIROS, Roberta, \& MOSINI, Amanda C. 2017. "Are we ready for a true biopsychosocial-spiritual model? The many meanings of 'spiritual". Medicines, 4(4):79.

ŞENEL, Engil \& DEMIR, Emre. 2018. "Bibliometric and scientometric analysis of the articles published in the Journal of Religion and Health Between 1975 and 2016". Journal of Religion and Health, 1-10.

SHORE, Cris \& WRIGHT, Susan (eds.). 2003. Anthropology of policy: perspectives on governance and power. Routledge.

SULLIVAN, Winnifred. 2014. A ministry of presence: chaplaincy, spiritual care, and the law. Chicago: University of Chicago Press.

TAYLOR, Charles. 2007. A secular age. Cambridge: Harvard University Press.

TONIOL, Rodrigo. 2014. "Integralidade, holismo e responsabilidade: etnografia da promoção de terapias alternativas/complementares no SUS”. In: Jaqueline Ferreira \& Soraya Fleischer (orgs.). Etnografias em serviços de saúde. Rio de Janeiro: Garamond. pp. 153-178.

. 2015a. Do espirito na saúde: oferta e uso de terapias alternativas/complementares nos serviços de saúde pública no Brasil. Tese de Doutorado, UFRGS.

- 2015b. "Espiritualidade que faz bem: pesquisas, políticas públicas e práticas clínicas pela promoção da espiritualidade como saúde." Sociedad y Religión, 25(43):110-146.

. 2016. "Cortina de fumaça: terapias alternativas/complementares além da Nova Era”. Revista de Estudos da Religiāo, 16(2):31-54.

VEER, Peter van der. 2009. "Spirituality in modern society". Social Research: an International Quarterly, 76(4):1097-1120.

2013. The modern spirit of Asia: the spiritual and the secular in China and India. Princeton and Oxford: Princeton University Press.

WHITE, Christopher G. 2008. Unsettled minds: psychology and the American search for spiritual assurance, 1830-1940. Oakland: University of California Press. 


\section{Resumo}

A presença da noção de espiritualidade nos documentos da Organização Mundial da Saúde é tão duradoura quanto pouco explorada, seja pelos estudiosos identificados com o campo da antropologia da saúde, seja pelos pesquisadores das ciências sociais da religião. Este texto é uma tentativa de cobrir parcialmente essa lacuna. Para tanto, recorro a atas, memorandos, transcrições de discursos, resoluçóes oficiais e relatórios que me permitem acessar como a ideia de espiritualidade foi acionada ao longo do tempo na instituição e, principalmente, como ela foi articulada com outras noçóes, como as de cultura, religião, direitos e bemestar. Diante desse material, realizo dois movimentos. Primeiro, explicito algumas das questóes que envolvem a análise do tema da "espiritualidade" nas ciências sociais da religiáo e justifico as razóes pelas quais este texto pode contribuir para tal debate. Segundo, detenho-me nos documentos analisados, apresentando-os a partir de dois eixos de variação: a espiritualidade dos Outros e a espiritualidade de todos. Explicitarei como esses dois eixos náo somente diferem, mas principalmente se articulam. Encerro o texto delineando um conjunto de consequências empíricas associadas à "oficialização da espiritualidade" na OMS e aponto para direçóes que novos investimentos analíticos sobre o tema podem seguir.

Palavras-chave: espiritualidade, Organização Mundial da Saúde, saúde, religião.
World Health Organization documents is as long-lasting as non explored, either by scholars identified with the field of health anthropology or by researchers in the social sciences of religion. This text is an attempt to reduce this gap. To do so, I analyze the minutes, official texts, transcripts of speeches, resolutions, and reports, and I reflect about how spirituality was enacted in the institution and, mainly, how this category has been articulated with other, such as culture, religion, rights, and wellbeing. The article has two main sections. First, I explain some of the questions related to the analysis of "spirituality" in the social sciences of religion and justify why this text can contribute to such debate. Secondly, I dwell on the documents analyzed, presenting them from two axes of variation: the spirituality of Others and the spirituality of All. On the conclusion I outline a set of empirical consequences associated with the "officialization of spirituality" in the WHO. Also, I point to directions that new analytical investments about this topic could follow.

Keywords: spirituality; World Health Organization; health; religion. 